E

.N54

no. 3

NMAIREF

\title{
THE GOLD TREASURE OF SIGSIG, ECUADOR
}

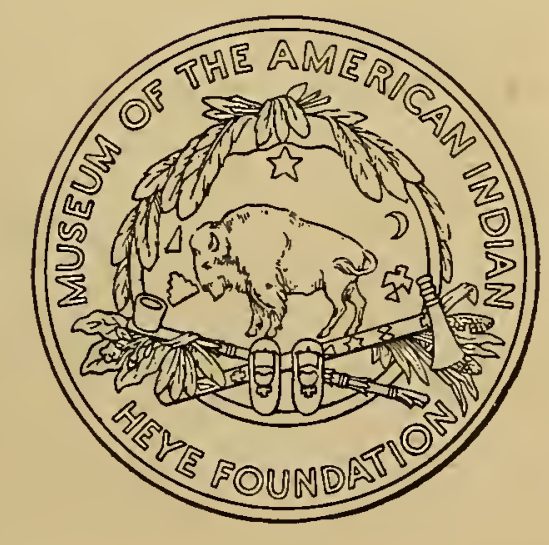

LEAFLETS OF THE MUSEUM OF THE AMERICAN INDIAN HEYE FOUNDATION, NEW YORK NUMBER 3 , ' SEPTEMBER 16, 1924 






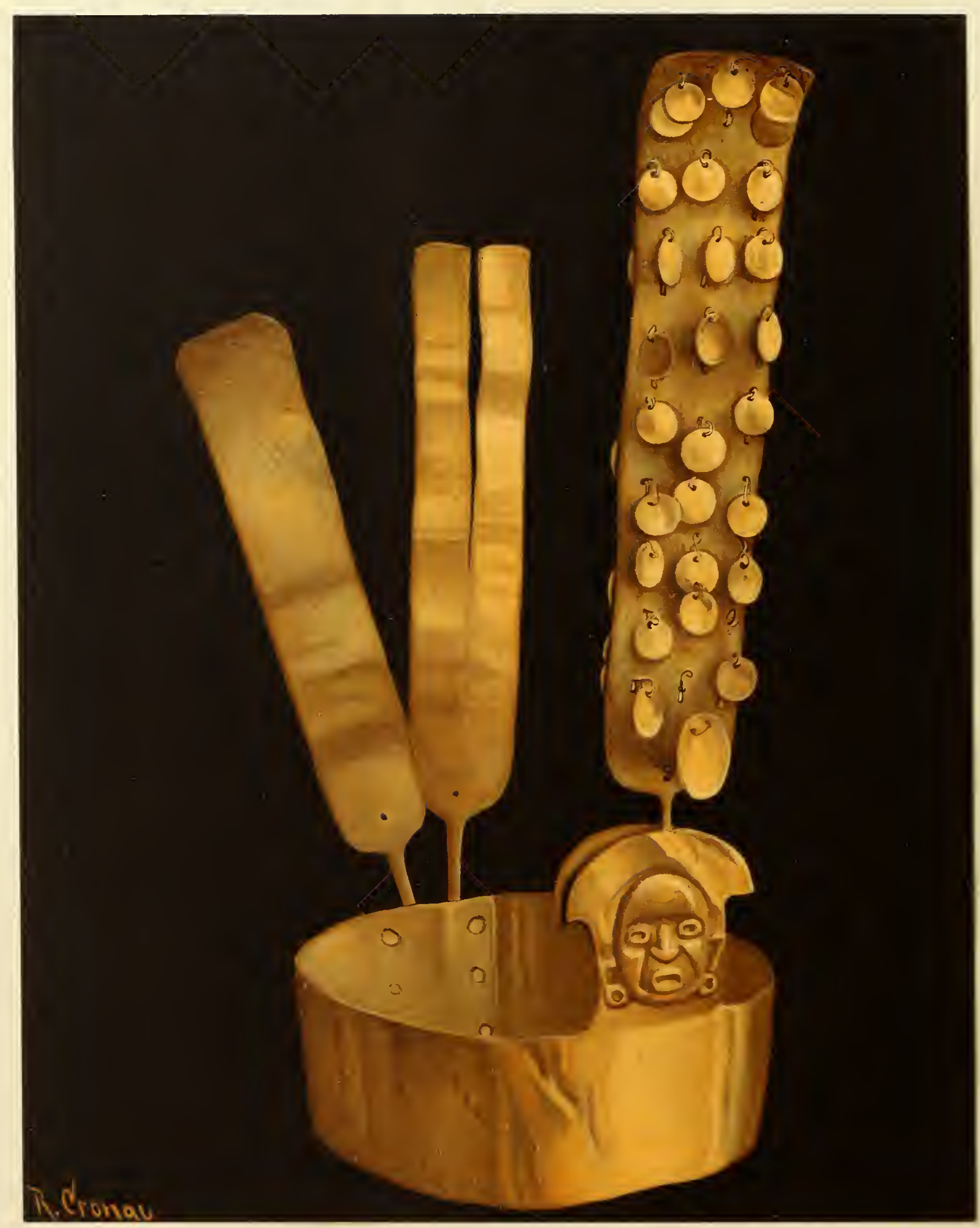

GOLD CROWN FROM SIGSIG 


\section{THE GOLD TREASURE OF SIGSIG, ECUADOR}

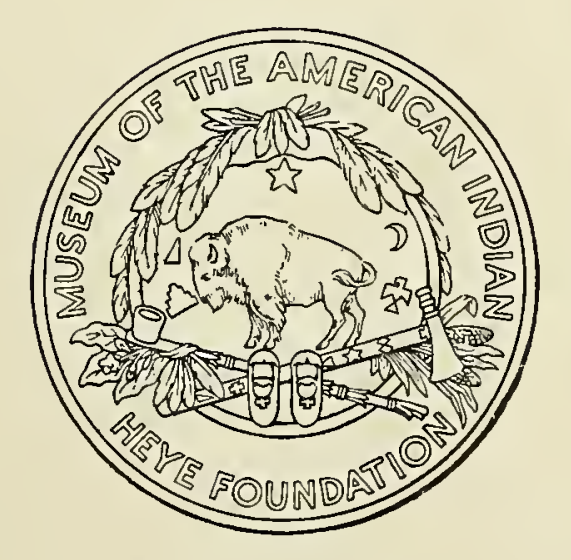

LEAFLETS OF THE MUSEUM OF THE AMERICAN INDIAN HEYE FOUNDATION , NEW YORK NUMBER 3 ' $\quad$ SEPTEMBER 16, 1924 
(10T 122005 
To

\section{GEORGE GUSTAV HEYE}

FOUNDER AND DIRECTOR OF THE MUSEUM OF THE AMERICAN INDIAN, HEYE FOUNDATION, THIS LEAFLET, WHICH TREATS OF A PHASE OF THE RESEARCHES BY THE SOUTH AMERICAN EXPEDITION, MADE POSSIBLE BY HIS MOTHER, IS PUBLISHED IN COMMEMORATION OF HIS FIFTIETH ANNIVERSARY AS A TRIBUTE BY HIS WIFE THEA HEYE

SEPTEMBER I6, I 924 



\section{The Gold Treasure of Sigsig, Ecuador}

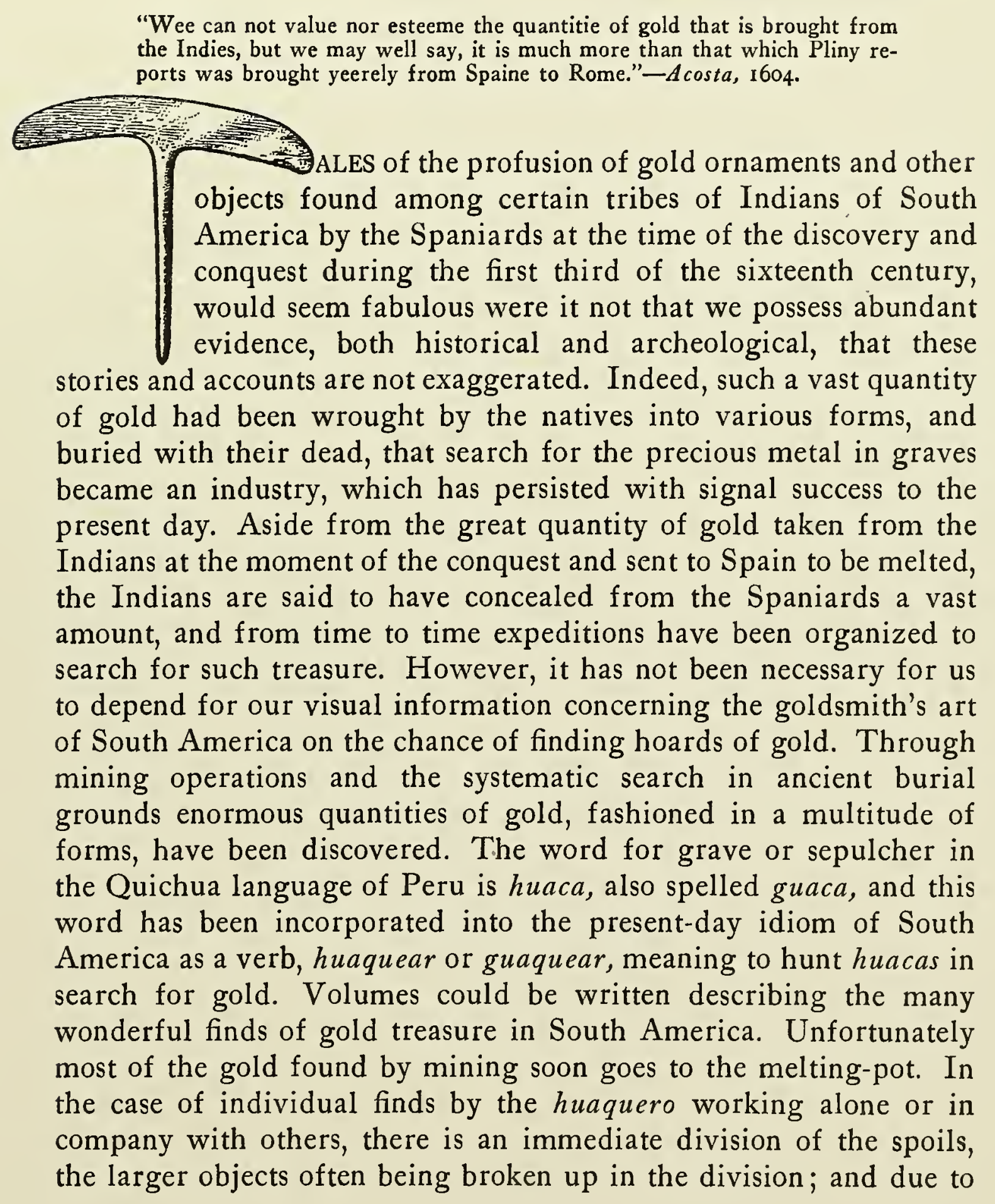




\section{THE GOLD TREASURE OF SIGSIG}

the laws of the various South American countries that a certain proportion belongs to the state, conforming to the old Spanish law that a fifth of all buried treasure became the property of the Crown, the finders conceal, so far as possible, the existence of such treasure from the authorities, and it is soon melted. Occasionally are preserved pieces which find their way into museums or private collections. The countries where gold is most abundant in graves are Colombia, Ecuador, and Peru.

Through the operations of placer mining and systematic search by the huaquero, two great fields in Colombia containing gold treasure have been exploited in recent times-one, the region of the Sinu river in the Department of Bolivar in the extreme northwestern portion of the republic, and the other in the Cauca valley. Enormous quantities of worked gold have been found in both areas. From the former region the Museum of the American Indian, Heye Foundation, has a wonderful collection. Cauca valley has long been famous for the remarkable gold figures, vessels, canisters, and other objects supposed to be of Quimbaya origin, a splendid collection of which, now in the Museo Arqueológico Nacional of Madrid, was presented by the Colombian Government to the Queen of Spain in I892. ${ }^{1}$

In Peru during the last decade at least two great treasures of gold have been discovered. The first was found at Cerro Zapamé, near Lambayeque, where an extraordinary find, now in the Brüning collection, was made, many of the pieces bearing close resemblance to those from Costa Rica. ${ }^{2}$ The other discovery was made at Huarmey, a little more than a hundred miles north of Callao. Here great plaques, discs, and vessels were unearthed. ${ }^{3}$ Both sites are on the coast and pertain to pre-Inca culture.

The ancient peoples of Ecuador were among the most proficient workers of gold in South America. From the very beginning of the Spanish conquest up to the present time an incalculable amount of gold treasure has been discovered in the tombs and graves in different parts of the country. Three regions of Ecuador are especially rich in treasure of the precious metal in ancient graves, namely, the Province of Esmeraldas on the Pacific coast, the Province of Carchi in 


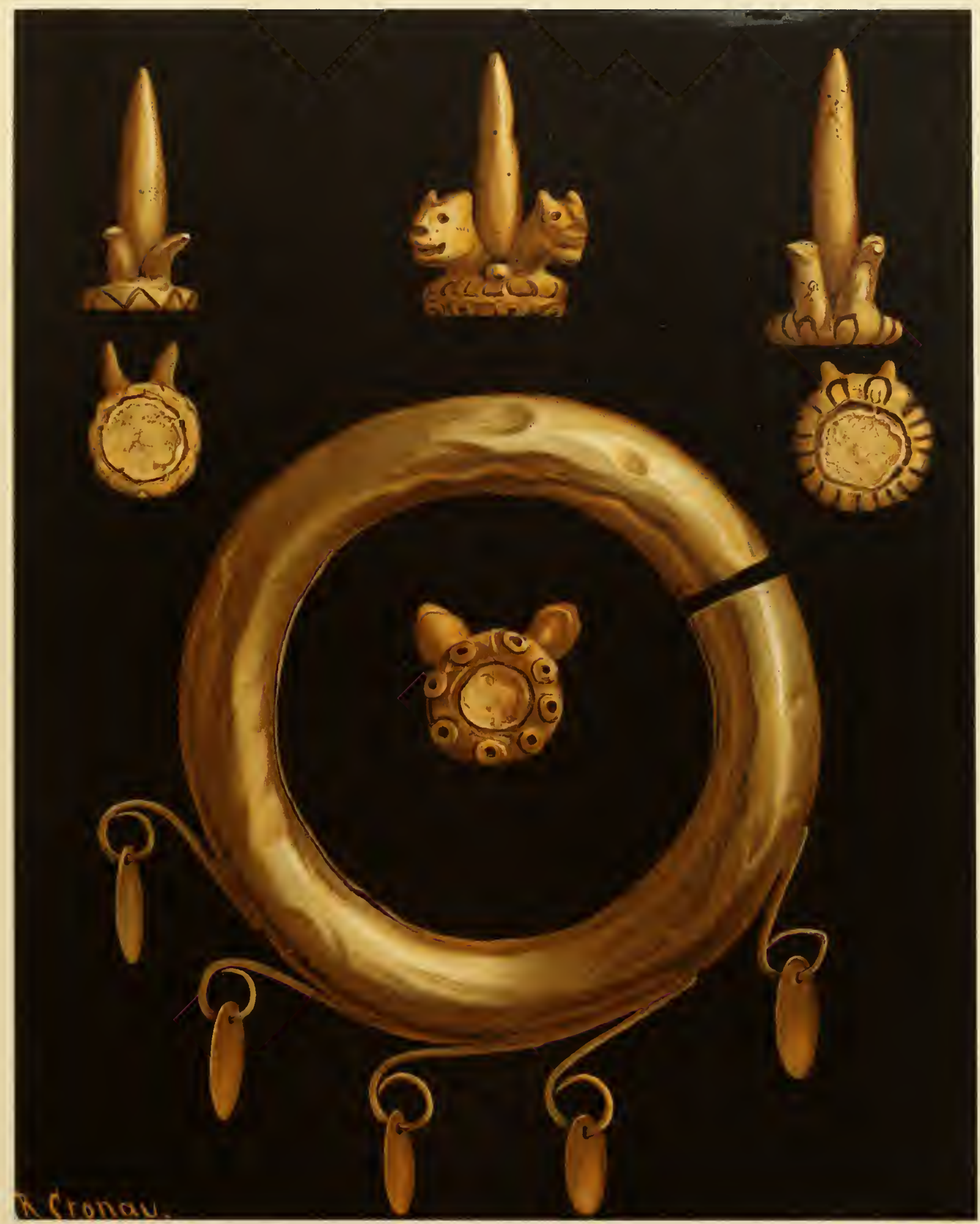

GOLD BRACELET AND SEALS FROM SIGSIG 



\section{THE GOLD TREASURE OF SIGSIG}

the north near the Colombian frontier, and the provinces of Cañar and Azuay in the south. The region of Esmeraldas has been the field of extensive investigations by the Museum under the direction of the writer, and the important results attained by the explorations, together with a study of the wonderful gold objects procured during these researches, will be described in another place. ${ }^{4}$

Considerable attention was paid to the antiquities of Carchi, but we were unable to obtain examples of the gold ornaments and other objects of the same material from that region. Our expedition was in that field during the year i9lo. We found that a few years before an ancient cemetery close to the town of Angel, in an open upland plateau, had been the scene of a veritable gold rush. The place was honeycombed with tombs, in the form of wells or shafts, varying from ten to fifty feet in depth and expanding into a bottle-shape chamber at the bottom. ${ }^{5}$ In these tombs a great quantity of gold was found by the excavators, practically the entire village camping on the site and engaging in the search. We obtained a very large and valuable collection of pottery vessels and stone artifacts which had been taken out at that time. There was not a single house in the town that did not contain some pieces, and many had been carried away and sold in Quito and other places. But the tangible evidence of the art of the goldsmith was missing, as all the objects had been sent to the melting-pot, hence we were able to judge of their character by only a few specimens preserved in the Museum of the University of Quito.

In the year IgI I a tomb was discovered at the little hill called Itschimbia on the outskirts of Quito. A considerable number of gold ornaments, some of large size, were found; these are now in the private museum of Sr. Jijón y Caamaño, who has described and figured them. ${ }^{6}$

Undoubtedly the greatest amount of gold treasure yet unearthed in Ecuador has been taken out of the ancient tombs of the Province of Azuay. In a recent very interesting and important paper, Sepulturas Ricas de Oro en la Provincia del Azuay, Dr. Max Uhle presents an account of various finds made at different times, about which he could obtain information, from which we gather certain facts 


\section{THE GOLD TREASURE OF SIGSIG}

relating to the subject. ${ }^{7}$ About three years ago the latest discovery was made in the region, when Dr. Uhle spent considerable time on the ground and gathered this authentic information. A great find was made at Patecte, near the little village of Chordeleg, about the year $1856 .^{8}$ Some of the important specimens were preserved, and drawings will be found in plates $V$ to VIII, which will be referred to later. Another great find was made at Sigsig in I889, and some of the objects found at that time form the subject of this paper. ${ }^{9}$ The latest discovery of this nature was made early in I 922 at Cerro Narrío, not far distant from the other sites, but in the Province of Cañar and in the neighborhood of the city of the same name. During the month of January practically the entire population of the immediate neighborhood, augmented by others from towns far away, flocked to the spot. Uhle mentions the fact that at one time about four hundred people were busily engaged in the despoliation of the cemetery, the hill appearing like an ant-heap. ${ }^{10}$

Other places where gold strikes of this character have been made in the provinces of Cañar and Azuay are enumerated by Uhle. Among them are: Zhiñang hill, Ganzhun, Pajtente, Huailil hill, Cumbre, Raranga region near Quinjeo, Curiloma vicinity of Cuenca, Guizhil hill, Bazhun, Patamarca, Machángara, Cojitambo, and Huapán. In all these places, and in many others, gold in greater or lesser quantity has been taken from tombs in recent years. The character of the places where the tombs are discovered is more or less as follows: They are divided into two classes: graves with skeletons, and places of offerings without skeletons. The former are the more frequent. They either form cemeteries or are in small groups, and very rarely an isolated one is encountered. They are generally discovered on the upland plains, occasionally on the tops of high hills. In shape the graves vary-some are circular, others rectangular. Sometimes there is a square chamber with a similar chamber at each corner. There are also tombs, as at Zhiñang, in the form of the figure 8 . The well-like tombs vary in depth: some are shallow, while others are from six feet to about forty feet in depth, and generally the diameter is about four to five feet. Many of the 


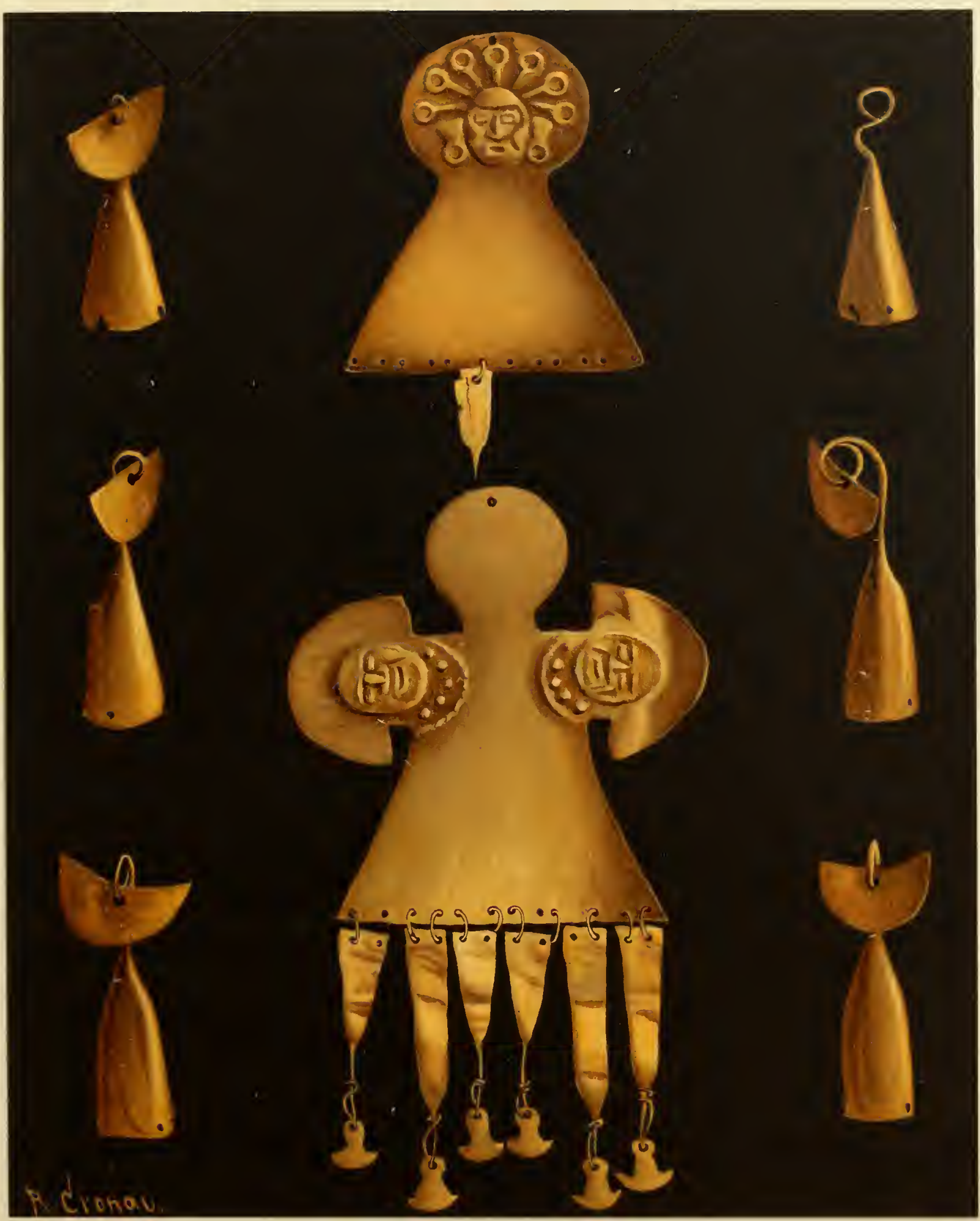

GOLD ORNAMENTS FROM SIGSIG 



\section{THE GOLD TREASURE OF SIGSIG}

tombs contain little side-chambers called bolsones, and much of the gold treasure is found in these chambers, well sealed. Uhle gives the weight of gold recovered from some of these tombs. Some contain very little, but in others an immense amount has been taken out. One tomb in Sigsig contained forty-four pounds of gold, another more than two hundred pounds. From a tomb in Urcur more than four hundred pounds of the precious metal were recovered, and others were reported in which hundreds of pounds were found. At Angel, in the Province of Carchi, about which we have already spoken, we were told a similar story regarding the enormous amount of gold taken from the tombs.

The forms of the objects include discs, plain or decorated, earrings, nose-rings, bracelets, bells, crowns called llautos, thick shields without wooden backs, musical instruments such as pan-pipes and flageolets, circular rings of massive gold sometimes weighing as much as three pounds, and semi-globular vessels and vases of different sizes and in great numbers. The thickness of the objects varies from a millimeter to a centimeter. Many of the objects are highly decorated with figures, lines, etc., some of which are made of gold and silver, the metals making different patterns with no sign of soldering. Numerous carved wooden staffs or canes, and spearthrowers, all made of the lasting wood of the chonta palm, were decorated with gold.

Let us now consider the gold treasure of Sigsig, a part of which is in the Museum of the American Indian, Heye Foundation. Near the close of the first year's work of the Marie Antoinette Heye Expedition to Ecuador, in September, 1906, I learned of the existence of a collection of gold objects from a Sigsig tomb, but had no opportunity to examine it until the eve of my departure from the country, when, fortunately, arrangements for its acquirement were made and I was enabled to bring it with me to the United States.

The story obtained in regard to the find was the following: It was discovered in July, 1889, by an Indian in the town of Sigsig, who, while digging a drain near the convent in the town, discovered a ferule of gold adhering to the end of a chonta-wood stick. This find 


\section{THE GOLD TREASURE OF SIGSIG}

aroused the interest of various persons, who deepened the excavation and discovered a tomb containing two skeletons in an advanced state of decay, together with a great number of gold objects, which were divided amongst the finders. Among the objects was a pan-pipe of gold and several spear-throwers of wood decorated with gold. Most of the pieces were soon thrown into the melting-pot, but a few were preserved by a curious individual. Mr. Nicolas A. Ribadenyra, of Guayaquil, soon heard of the find and made a visit to Sigsig, where he was successful in buying the little lot which we later had the good fortune to procure from him. It was exhibited at the Exposición de la Filantrópica del Guayas, in Guayaquil, in November, 1899, and received a first prize, a gold medal. In 1904, Archbishop González Suárez published a paper, Prehistoria Ecuatoriana, in which are reproduced photographs of some of the objects, accompanied with a brief description. ${ }^{11}$ In I9I2, Verneau and Rivet, in their Ethnographie Ancienne de l'Equateur, reproduced distorted photographs of most of the objects. As Dr. Rivet has spent years in Ecuador, and has personally visited the site, an opportunity which we did not have, and inasmuch as he obtained two of the specimens found in the Sigsig tomb, namely, two spear-thrower shafts, we translate his account of what he learned about the discovery of the tomb and his description of the spear-throwers. He writes:

"In order to bring to a close our study of well-like sepulchers, we will now describe a tomb discovered in the vicinity of Sigsig, in the region of the Cañaris, remarkable for the great quantity of interesting objects, mostly of gold, found therein. Even though we were not present at this excavation, we have been able, thanks to the information which the people gave us, to reconstruct a fairly accurate plan of the tomb. The shaft had a depth of one meter seven centimeters, being quite shallow, with a bolson to the east of little depth. A skeleton was found lying on the floor of the tomb, the head resting at the entrance of the bolson. Over the skeleton was found a great quantity of gold and silver plates, alternating regularly, as if they had been affixed to a cloak thrown over the body. This cloak may also have had a fringe formed of small tubes of gold. The arms

$$
\text { [10] }
$$



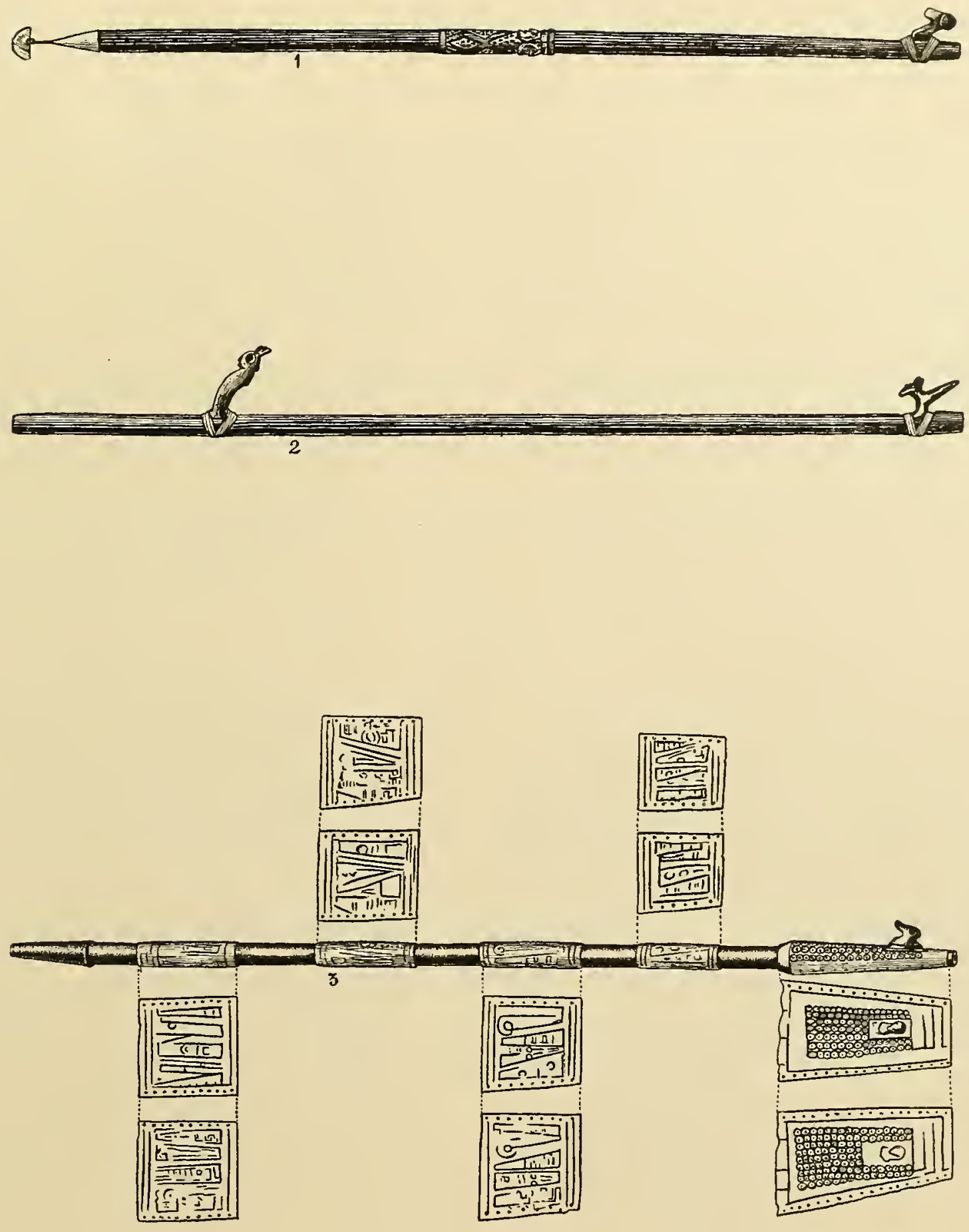

SPEAR-THROWERS FROM SIGSIG, DECORATED WITH GOLD 


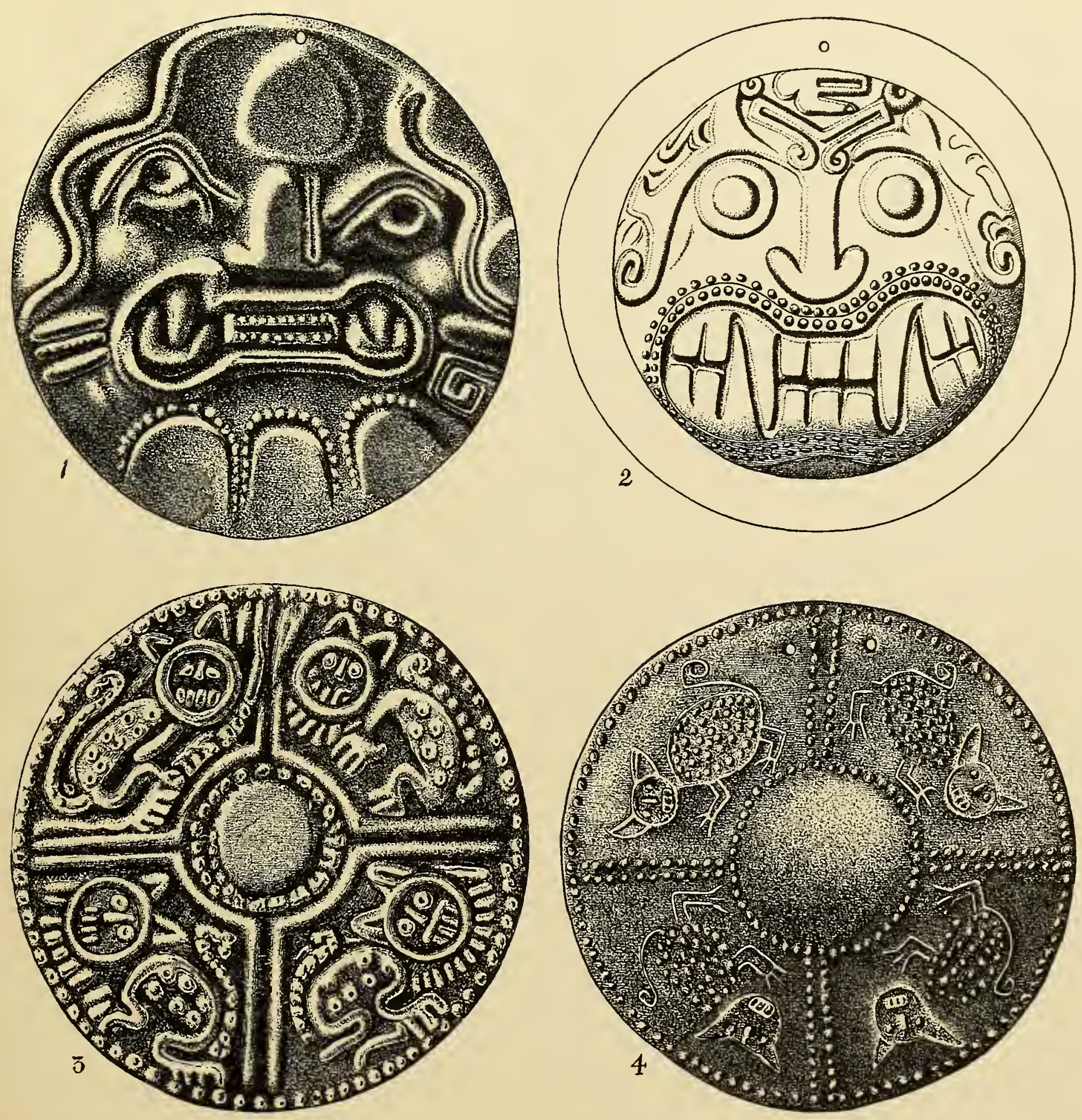

GOLD BREASTPLATES FROM NEAR CHORDELEG 



\section{THE GOLD TREASURE OF SIGSIG}

were decorated with bracelets, and the head with a crown, all of gold. [See plates I, II.] At the entrance of the bolson was found a great bundle of chonta-wood sticks, chased and covered with lamellæ of gold and silver; in the center of the bundle were two sticks of smaller dimensions covered with lamellæ of gold. Farther on in the bolson four circular plates of gold and silver; alternating two of gold and two of silver, ranging from forty to fifty centimeters in diameter, were placed vertically so as to cover the opening completely. Finally, behind them was found a veritable treasure, consisting of needles, hatchets, pan-pipes, and figurines, all of gold, besides a feather, the shaft of gold and the plumage of silver. In an analogous excavation in the same region were discovered the objects described by Heuzey as the 'treasure of Cuenca.'

"We possess in our private collection two analogous staffs, which, although lacking their hooks, leave no doubt as to their intended use. . . . These two interesting pieces came from this tomb of Sigsig, particularly rich in objects of gold and silver, which we have described above in detail. They formed a part, as we have stated, of a considerable series of similar instruments gathered in bundles; also we should not be surprised if the specimen figured by González Suárez came from the same deposit. The first of these sticks [see plate IV, no. I] measures thirty and five-tenths centimeters in length. It is of a brilliant black hardwood, doubtless chonta (Astrocaryum sp.). One of its extremities, which we will designate the upper, is finished with a clean perpendicular cut of an axe, while the other end tapers to a point, which measures fifteen millimeters in length. About the middle of the stick, for an approximate length of eight centimeters, it has sculptures representing human heads. Also the most interesting detail, from the point of view which interests us, is a rectangular cavity of twenty-five millimeters in length, seven millimeters in breadth, and five millimeters in depth, hollowed out at a distance of fifteen millimeters from the upper end. On the other or under surface of the stick from the side upon which is found this excavation there exists a row of little holes, similar to those made with a small awl, continued over the entire length

$$
\text { [II] }
$$




\section{THE GOLD TREASURE OF SIGSIG}

to the staff save at the level of the sculptured heads. In order not to penetrate one of the heads the line is deviated at an angle of forty-five degrees in such a way as to pass between the two other or opposite heads. Inasmuch as we know that at the time when the object was discovered it was covered with gold and silver leaf, it is evident that these orifices are in accordance with the method of affixing these plates, either by the use of little gold nails or, perhaps, the gold of the plates was pressed into each of the holes. From all its details this staff cannot be considered as other than a thrower for state occasions. Several of the hooks of our collection fit perfectly in the cavity, and in order to give an idea of the instrument we have made a restoration.

"The second staff of our collection is more simple, but even more instructive than the preceding one. It also is cylindrical, is made of chonta-wood, and its length is forty-nine and one-half centimeters, while the diameter is fourteen millimeters. Its two extremities are marked by clean cuts of an axe. At a distance of eight centimeters from one end and fifteen centimeters from the other are found two cavities similar to that of the preceding staff; these are placed not in line with each other, being a quarter of a circle apart. This piece also was certainly covered with metallic plates over its entire length, for there is visible a longitudinal row of little holes, regularly spaced at approximately six millimeters apart. It is evident that one of the cavities was intended for the hook, while the other served for inserting a handle, as seen in our reconstruction." ${ }^{12}$ (See plate IV, no. 2.)

The other spear-thrower from Sigsig has been illustrated by González Suárez, who did not recognize it, however, as one of these implements. ${ }^{13}$ He calls it a scepter, in which he is not far wrong, for it was certainly not used in actual warfare, but was part of the ceremonial paraphernalia of a high priest or chief. It is slender, about fifty centimeters long, is made of chonta-wood, and bears some plates of gold at intervals. In a cavity near one end is a stone hook, representing the head and breast of a bird. The gold plates are decorated with drawings in relief. (See plate IV, no. 3.)

$$
\text { [I2] }
$$




$$
\text { 敌 }
$$





\section{THE GOLD TREASURE OF SIGSIG}

The pieces of the Sigsig treasure in the Museum of the American Indian, Heye Foundation, are illustrated in colors in plates I to III. Plate I is the crown, or llauto, with plumes like aigrets. As it has already been described in detail by Rivet, we shall allow the illustration to tell the story. Suffice it to say that it is much reduced in size in the plate, as it is large enough to fit a head of ordinary size. There is no soldering at the back of the band above which rise the two plumes, the two ends of the strip being riveted together with six tacks. The bangles on the front plume are held by little gold wires. A similar crown, lacking the plumes, is figured in plate VI, no. 3. Three tiny perforations are found in the semilunar projection above the human face in relief. This crown is said to have come from Sigsig, and it is believed to be now in Munich.

Plumes or aigrets similar to those of the Sigsig crown, as well as tiaras of thin gold, have been found on the Peruvian coast, and a number have been illustrated by Baessler. ${ }^{14}$ The traveler Vigne was shown in the cabildo of Quito in the year 1852 a crown of nearly pure gold, said to have been dug up in the vicinity of Cuenca. ${ }^{15}$ Ulloa, who was in Ecuador about the year I740, wrote that shortly after he arrived in the country a huaca was opened on the plains of Pesillo near Cayambe, Province of Pichincha, in which much worked gold was found, and some of the pieces were preserved in the Caxa Real, Quito, being the fifth part pertaining to the Crown. He also stated that about that time another huaca was discovered in the jurisdiction of Pasto, northern Ecuador, and some pieces of its gold treasure were brought to Quito. None of the specimens now exist, probably having been melted years ago. ${ }^{16}$

All the objects illustrated in plates II and III are given actual size. The most prominent object in plate II is the bracelet, hollow, and having five bangles attached. The other three specimens, probably seals or stamps, are of massive gold. Two ornaments in plate III were probably intended to be attached to the clothing and hung over the breast. The human faces which decorate them are of the same technic as the faces on the two crowns. Only one of the twelve bangles that hung pendent remains on the upper ornament, 


\section{THE GOLD TREASURE OF SIGSIG}

but those on the lower one are intact. The other six objects have already been referred to. They formerly decorated the ends of ceremonial staffs and spear-throwers of chonta-wood, as seen in plate IV, no. I.

Specimens from the great find made at Patecte, near Chordeleg, in I 856 , are in European museums. Some of these pieces were first described by Heuzey in I 870 . Recently Dr. Rivet has republished photographic illustrations of the specimens. In plates $V$ to VII all but one of the objects are probably from this hoard. In plate $V$ drawings of four breastplates are grouped. No. 4 was published by Heuzey, while nos. I and 3 appear for the first time in the work of Rivet. The two upper specimens are somewhat similar, both resembling the heads of felines, but believed by Rivet to be conventionalized human faces. They recall the beautiful gold disc from Cuzco, lately illustrated by the writer, which is now in the Museum. ${ }^{17}$ No. I is drawn from Rivet's photograph. The other disc (plate $v$, no. 2) is copied from what is evidently a not very accurate drawing published in 1860 by Bollaert, ${ }^{18}$ who states that it was found in a tomb near Cuenca. Lack of knowledge of the definite locality is not highly important, as the region around Cuenca, in which are the sites of Paute, Gualaceo, Chordeleg, Quinjeo, and Sigsig, is one culture area, and the specimen from "near Cuenca" apparently belongs to the same epoch as the treasure of Sigsig. Bollaert describes the disc as follows: "The center or face is embossed, more than half an inch high; the rim is flat: a small circular raised plate and wire (not shown in our drawing) attaches the mask to three hollow rings. There are twelve small globular bodies, joined six and six, movable on a wire. There is the appearance of soldering about the large hollow rings. The embossing over the face looks like an hieroglyph. This ornament was worn by a chief or priest, and may be the head of a war-deity. There is attached a flat pear-shaped piece of gold."

In the Liverpool Museum is a specimen of gold, apparently a breastplate like the above, described in the catalog as follows: "Large ear-pendant in gold. One large ring to which is attached an embossed plate in the shape of a grotesque face showing teeth. On the

$$
\text { [14] }
$$



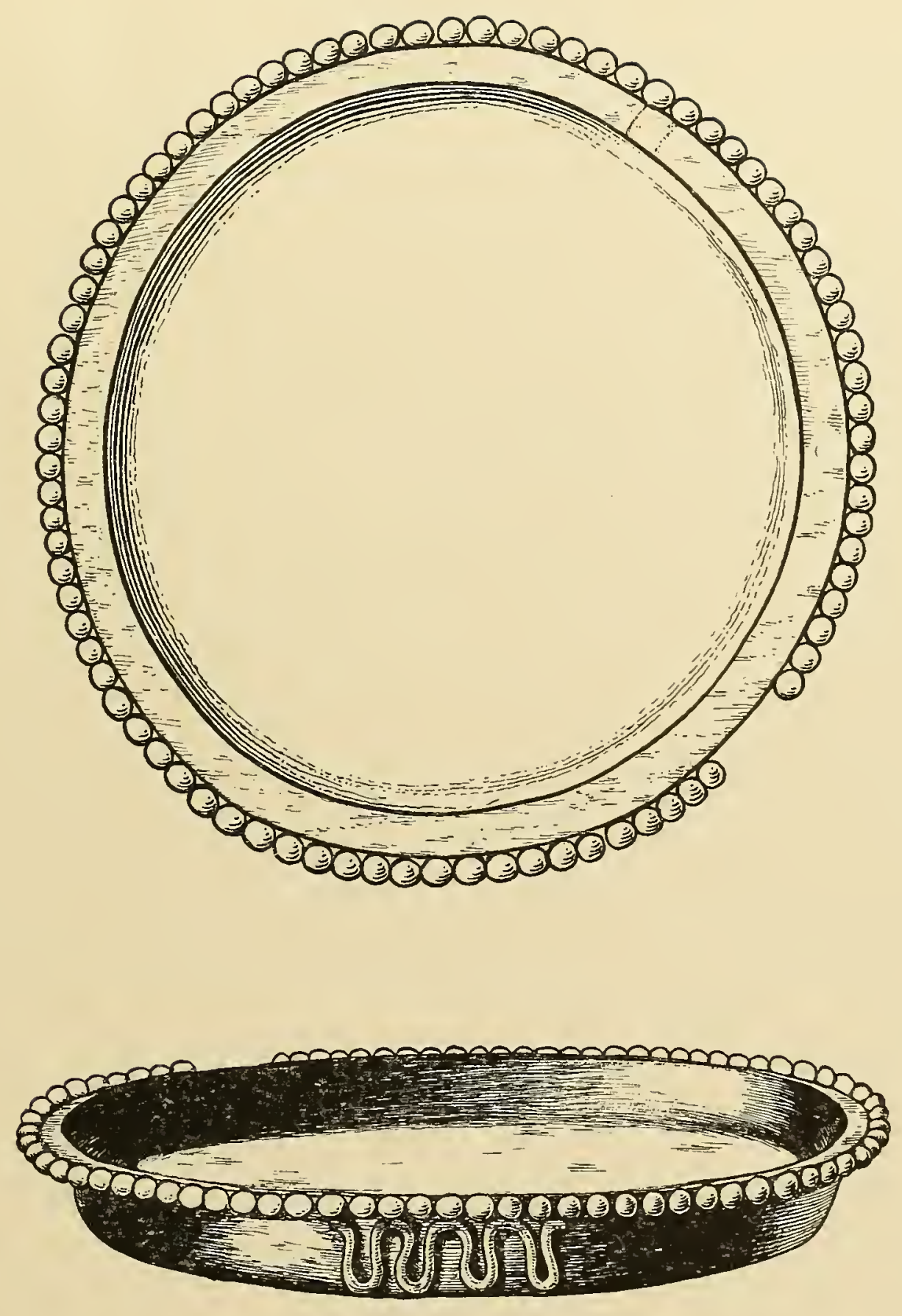

GOLD DISH FROM NEAR CHORDELEG 



\section{THE GOLD TREASURE OF SIGSIG}

forehead are figures which $\mathrm{Mr}$. Bollaert considers may be hieroglyphs. An almost exactly similar pendant is figured by Mr. Bollaert's Antiquities of South America.... Probably found at Cuenca. Diameter of the large boss four and seven-eighth inches."

In plate VI, nos. I and 2, are objects classified by González Suárez as a crown or tiara, and a helmet. No. I was first illustrated by González Suárez, and No. 2 by Heuzey. They are of a type entirely different from that of the two crowns from Sigsig just described.

A remarkable dish from the same locality is shown in plate VII, and in plate VIII, no. 3 , is a cup illustrated for the first time by González Suárez. The human figure on the side wears an elongate cap or crown of peculiar type. A richly ornamented star-club-shape weapon, having a projecting section resembling a blade with two animal heads, is shown in plate VIII, no. I. The open-work of this blade is like that of the axe illustrated in the same plate, no. 2. This is one of a number of similar axes found near Chordeleg, each having a slightly different open-work pattern. The last specimen of the remarkable pieces from Azuay to be illustrated (plate VIII, no. 4) is described by González Suárez as a great plate of solid gold, the designs in relief apparently having been made by hammering over a wooden model. No dimensions are given, but from the description the specimen must exceed eighteen inches in diameter.

In the Berlin Ethnographical Museum are two specimens of wood from Chordeleg. One is an engraved rod of chonta, forty-seven centimeters long, probably a ceremonial staff similar to the staff found in Sigsig. The other piece is a wooden flute, twenty-five centimeters long; it has gold rings at the end, and a figure carved on the body of the instrument is covered with silver.

Two remarkable stone hooks for spear-throwers of chonta-wood have been described by Jijón y Caamaño as follows: "Not long ago there were found in the town of Chordeleg two spear-throwers, which were broken up in order to obtain the metal from them. The huaqueros preserved only the little heads worked in stone as curious objects, and they are now preserved in my collection. One worked in opal is a veritable jewel of lapidarian work, and represents the 


\section{THE GOLD TREASURE OF SIGSIG}

head of a young man ornamented with a cap with two sharp points; the other is in the form of the head of a bird." 19

The region of Cañar and Azuay was in former times under the dominion of the Cañaris, and only three generations of Incas had held sway over the country before the coming of the Spaniards. As Uhle observes, the immense amount of worked gold taken out of the graves here shows nothing of Inca (Quichua) influence. They must be attributed to the Cañaris, of whom we have an important description from Cieza de León. ${ }^{20}$ From the objects of pottery, stone, wood, and metal we may judge that the Cañaris were one of the most advanced tribes of ancient Ecuador before the coming of the Incas. Their culture may be placed on a plane with the pre-Inca cultures of the coast of Peru, and the goldwork of the Cañaris resembles closely that of the pre-Inca culture of that region. Uhle classifies the remains in this region as of two pre-Incan epochs, the first of which he calls the Tiahuanaco period, and the second the Tacalzhapa period. He attributes the greater part of the gold objects which we have described and figured to the first period, which he states is of slightly higher esthetic development. The basis of his differentiation of the two periods is that the pottery found with the objects attributed to the second period is much thicker and is painted, while that of the first period is not painted. Furthermore, numerous potsherds of this thick painted pottery are found on the surface. The influence of the Incas in this region was very weak, so far as modifying the native Cañari art is concerned. There is no difficulty whatsoever in distinguishing artifacts of Inca origin.

As a final word, we may say that the picture presented by the occurrence of such vast quantities of gold artifacts in the various culture areas of South America to which we have called attention, and amply demonstrated through the evidence brought out, shows a glittering magnificence in connection with the ceremonial and civic life of the people which perhaps was not excelled even in ancient Egypt or Etruria. A fuller treatment of this subject would involve consideration of the native architecture, for there is evidence that precious metals were used to sheath the buildings in important cities. ${ }^{21}$ 

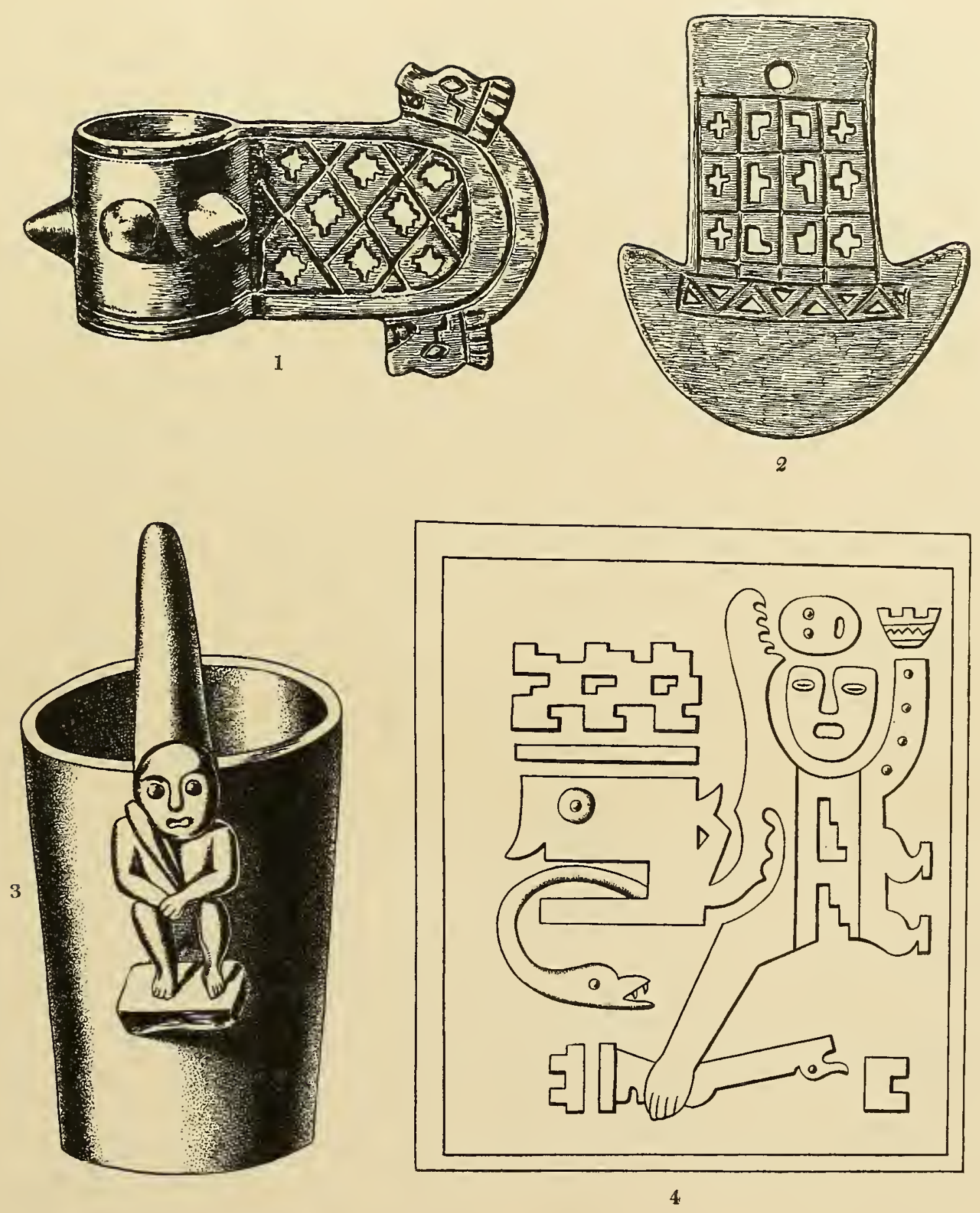

GOLD WEAPONS, CUP, AND PLAQUE, FROM NEAR CHORDELEG 



\section{NOTES}

1 Some of these marvelous hollow gold figures have been illustrated in colors by Restrepo. See list of works following. Seler and Farabee have also published numerous illustrations of specimens from this culture area.

${ }^{2}$ In a recent publication, The Art of Ancient Peru, Dr. Lehmann has given us illustrations (pp. 19-2I) of thirteen of the specimens from this find, now in the Brüning collection.

${ }^{3}$ Many of the pieces found at Huarmey are in the American Museum of Natural History, New York, and have been figured by Goddard. See list of works.

${ }^{4} \mathrm{~A}$ brief preliminary description of this gold-bearing region has been published by the writer in Archæological Researches on the Coast of Esmeraldas, pp. 340-342.

5 Numerous plans and descriptions of these tombs, both in the Province of Carchi and in the neighboring Province of Imbabura, have been published by Verneau and Rivet (see list of works), and in the monograph of Jacinto Jijón y Caamaño, entitled Contribución al Conocimiento de los Aborígenes de la Provincia de Imbabura en la República del Ecuador. Estudios de Prehistoria Americana. II. Madrid, 1915.

${ }^{6}$ See list of works.

7 Consult the two papers by Dr. Uhle referred to in the list of works.

${ }^{8}$ The paper on the subject of the Chordeleg finds, by Heuzey, published in 1870 , is very rare. All of the specimens figured by him will be found in the work of Rivet.

${ }^{9}$ As will be noted later, two accounts of this find have been published respectively by González Suárez and Rivet.

10 It is difficult to understand the attitude of the Government in allowing such ruthless destruction of archeological treasures, whereby priceless information regarding the ancient history of the country is forever lost.

${ }^{11}$ Archbishop Federico González Suárez has been the most efficient and truthful historian of Ecuador. He has rendered an inestimable service to his country by the numerous historical and archeological works which he produced up to the time of his death several years ago. The mantle was taken up by Jijón y Caamaño and Cárlos M. Larrea, in the publication of the Boletin de la Académia Nacional de Historia, founded by Jijón y Caamaño.

12 Pages 123-124 and 199-201. See Verneau and Rivet in the list of works.

13 Prehistoria Ecuatoriana, pp. 82-83.

14 See Baessler, Ancient Peruvian Art, first volume, plate 26. Two crowns of silver, each with a single plume, are illustrated in numbers 127 and 128 .

${ }^{15}$ G. T. Vigne, Travels in Mexico, South America, etc., vol. II, p. 193. London, 1863.

${ }^{16}$ Relación Historica del Viage a la America Meridional, por Jorge Juan y Antonio de Ulloa, primera parte, tomo segundo, pp. 618-619. Madrid, 1748 .

17 The golden breastplate from Cuzco, first illustrated by Bollaert, is the most important specimen of its class.

18 Bollaert, pp. 92-93. See the list of works.

19 Op. cit., note 5 , p. 123 . 


\section{NOTES}

${ }^{20}$ The Travels of Cieza de León, A. D. 1532-50, contained in the First Part of his Chronicle of Peru. Translated and annotated by Clements R. Markham. Hakluyt Society Publications, number 33. London, 1854 .

${ }^{21}$ The Italian Benzoni came to the New World in 1542, where he remained for fourteen years. In his Historia del Mondo Nuovo, first published at Venice in 1565, he gives many notices concerning the occurrence of worked gold in South America. He states that at one time the Spaniards secured more than twenty-five hundred pounds of worked gold which the Indians had hidden. This was in Darien. He speaks of the temples of the Incas being "large and sumptuous, the walls being adorned with sheets of gold and silver." The manner of working gold he describes as follows: "In the first place, when they wish to melt the metal, they put it into either a long or round grisolo, made of a piece of cloth daubed over with a mixture of earth and pounded charcoal; when dry, it is put into the fire filled with metal; then several men, more or less, each with a reed, blow till the metal is fused. It is now taken out, and the goldsmiths seated on the ground, provided with some black stones shaped on purpose, and helping each other, make, or, more correctly speaking, used to make during their prosperity, whatever they were commissioned to do; that is, hollow statues, vases, sheep [llamas, etc.], ornaments, and, in short, any animal they saw." 


\section{LIST OF SOME WORKS RELATING TO GOLD OBJECTS FROM WESTERN SOUTH AMERICA}

Arsandaux, H., and Rivet, P. L'Orfèvrerie du Chiriqui et de Colombie. Extrait du Journal de la Société des Américanistes de Paris, nouvelle série, tome xv, Paris, I923.

Baessler, Arthur. Ancient Peruvian Art. Contributions to the Archæology of the Empire of the Incas. Leipzig, 1902-1903.

Bollaert, William. Antiquarian, Ethnological and Other Researches in New Grenada, Ecuador, Peru and Chile. London, 1860.

Créqui-Montfort, G. de, and Rivet, P. Contribution a l'Étude de l'Archéologie et de la Métallurgie Colombiennes. (Avec la collaboration de H. Arsandaux, pour la partie métallurgique.) Extrait du Journal de la Société des Américanistes de Paris, nouvelle série, tome XI, I9I4-I919, Paris, I9I9.

Farabee, W. C. A Golden Hoard from Ecuador. The Museum Journal, University of Pennsylvania, Philadelphia, March, I92I.

- Ancient American Gold. The Museum Journal, University of Penn-

sylvania, Philadelphia, September, 1920.

Goddard, Pliny Earl. Peruvian Gold of the Chimu Kingdom. Natural History, vol. XxI, no. 5, New York, Sept.-Oct., I92 I.

González Suárez, Federico. Estudio Historico sobre los Cañaris, Antiguos Habitantes de la Provincia del Azuay en la Ecuador. Quito, 1878. - Prehistoria Ecuatoriana. Quito, I904.

Heuzey, M. L. Le Tresor de Cuenca. Extrait de la Gazette des Beaux-Arts, Paris, 1870.

Holmes, William H. The Use of Gold and Other Metals Among the Ancient Inhabitants of Chiriqui, Isthmus of Darien. Bull. (3), Bureau of Ethnology, Smithsonian Institution, Washington, 1887 .

Jijón y Caamaño, Jacinto. El Tesoro del Itschimbia (Quito-Ecuador). Estudios de Prehistoria Americana, I. London, n. d.

Lehmann, Walter. The Art of Old Peru. New York, 1924.

MacCurdy, George Grant. A Study of Chiriquian Antiquities. Memoirs of the Connecticut Academy of Arts and Sciences, vol. III, New Haven, March, I9II.

Restrepo Tirado, Ernesto. Ofebrería de las Tribus Quimbaya y Chibcha. El Centenario, pp. 340-345, plate with 7 figs. in colors, Madrid, I892.

Rivet, P. Note Complémentaire sur la Métallurgie Sud-Américaine. Extrait du Journal de la Société des Américanistes de Paris, nouvelle série, tome XIII, Paris, I92I.

Saville, Marshall H. Archæological Researches on the Coast of Esmeraldas, Ecuador. Separat-abdruck aus den Verhandlungen des XVI Internationalen Amerikanisten-Kongresses, Wien, 1909.

- A Golden Breastplate from Cuzco, Peru. Indian Notes and Monographs, Museum of the American Indian, Heye Foundation, Misc. no. 21, New York, I92I. 


\section{LIST OF WORKS}

Seler, Eduard. Die Quimbaya und ihre Nachbarn, Gesammelte Ablandlungen zur Amerikanischen Sprach- und Alterthumskunde, funfster Band, Berlin, 1915.

Uhle, Max. Sepulturas Ricas de Oro en la Provincia del Azuay. Boletin de la Academia Nacional de Historia, tome Iv, num. 9, Quito, Jan.-Feb., I922.

. The Excavations at Cañar. The Pan American Magazine, vol. xxxiv, no.

4. London, April, 1922.

Verneau, R., and Rivet, P. Ethnographie Ancienne de l'Equateur. Mission de l'Equateur, Ministère de l'Instruction Publique, tome 6, premier fasicule, Paris, 19 I2.

Wright, Bryce. Description of the Collection of Gold Ornaments from the Huacas or Graves of Some Aboriginal Races of the North Western Provinces of South America, belonging to Lady Brassey. London, $\mathrm{I} 885$. 


